\title{
The determinants of fertilizer microdosing adoption and impact on sorghum and maize yields in Burkina Faso
}

Mamadou Sanogo ${ }^{1 *}$ Frederic Gaspart ${ }^{1}$ Daniel Kabore ${ }^{2}$ Sibiri Jean-Baptiste Taonda ${ }^{3}$ Marie-Paule Kestemont ${ }^{4}$

1. Faculty of Bioscience Engineering, Earth and Life Institute, Université Catholique de Louvain, PO box Croix du Sud, 2 bte L7.05.15 B-1348-Louvain-la-neuve, Belgium.

2. Centre d'Analyse des Politiques Economiques et Sociales, 01 BP 1919 Ouagadougou 01, Burkina Faso.

3. Institut de l'Environnement et de Recherches Agricoles, 04 BP 8645 Ouagadougou 04, Burkina Faso.

4. Faculty of Science, Louvain school of Statistics, Biostatistics and Actuarial Science, Université Catholique de Louvain, LRIM, Place des Doyens 1/L2.01.02, 1348 Louvain-la-Neuve, Belgium.

* E-mail of the corresponding author: madousanogo33@gmail.com

This research is financed by Académie de Recherche et de l'Enseignement Supérieur (ARES) and supported by Université Catholique de Louvain (UCL), Belgium.

\begin{abstract}
Fertilizer microdosing was developed in order to increase farmers' income through improvement of fertilizer use efficiency and investment cost reduction in the drylands of West Africa. The purpose of this study is to identify the determinants of fertilizer microdosing fertilization and to analyze its impact on sorghum and maize yields in Burkina Faso. Using endogenous treatment regression model with data collected on 1057 famers in 2011, the findings reveal that access to warrantage credit, participation in training and labor availability are the main factors in the adoption of fertilizer microdosing. In terms of impact, the study shows that fertilizer microdosing contributed to significantly increase sorghum and maize yields by $55 \%$ and $37 \%$ respectively. The results of this study challenge us to accelerate the process mechanization of fertilizer microdosing fertilization, the establishment of infrastructure such as warrantage shops and farmers' capacity building.
\end{abstract}

Keywords: fertilizer microdosing, endogenous treatment regression, sorghum, maize, Burkina Faso.

DOI: $10.7176 / \mathrm{JESD} / 11-6-13$

Publication date:March $31^{\text {st }} 2020$

\section{Introduction}

Agricultural technologies play a crucial role in improving agricultural productivity and income in semi-arid regions in West Africa and particularly in Burkina Faso. In these countries, the production system is mostly extensive and characterized by low use of mineral fertilizers and organic amendments, which are essential for increasing agricultural yields (FAO, 2013; Bado et al., 2007). In addition, this low fertilization rate and technology adoption are often due to physical and financial inaccessibility and some farmers' misunderstanding (Holtzman et al., 2013). Thus, agricultural research has focused on the development of innovative agricultural practices such as microdose, which are adapted to agronomic, socio-economic and institutional context.

Fertilizer microdosing or hill placement technology, introduced in the 1990s, consists of applying small amounts of mineral fertilizer per hole at planting or a few days after emergence (Hayashi et al., 2018; Tabo et al., 2007). Its application is very useful to agricultural farmers, especially small farmers. This technology helps to minimize fertilizer costs and increase use efficiency of fertilizer (Aune and Bationo, 2008).

In general, the results of some studies evaluating the economic impact of fertilizer microdosing fertilization found a significant increase of farmers' income and an improvement in their food security (Bagayoko et al., 2011; Fatondji et al., 2016; Okebalama et al., 2017; Tabo et al., 2007). However, analysis of these studies shows that the approaches used (partial budget benefit-cost ratio and net income) used did not make it possible to assess the real impact of fertilizer microdosing on yields because of its interaction with socio-economic and agronomic factors. In other words, the analyses essentially considered the farmers as a homogeneous group up to some heterogeneity factors. In fact, heterogeneous technical, economic, biophysical and environmental factors and a wide range of production objectives (Vanlauwe et al., 2014) characterize farmers. In addition, farmers face many constraints such as inaccessibility to input, labor unavailability and lack of information, which could justify the rate of fertilizer microdosing adoption and explain its yield effect. 
The purpose of this study is to identify the determinants of fertilizer microdosing adoption and to assess its impact on sorghum and maize yield. In other words, we use a production function approach to identify socio-economic and institutional factors of fertilizer microdosing adoption and to measure its impact on crops yield.

\section{Theoretical framework of production function}

The production function is a quantitative relationship between inputs and outputs. By introducing a new technology, the analysis tries to estimate its influence on production using a regression method often used to measure the impact of inputs on total production.

Mathematically, $Y=f(X)$ where $Y$ is the production, $X$ the vector of inputs, $f$ the form of the relationship between $Y$ and $X$. This method makes it possible to estimate the marginal products of inputs, the elasticities and regression coefficients. One of weaknesses is the identification of exogenous factors that can explain the production. Other approaches such as instrumental variables, fixed-effects or random-effects models, linear regression models with endogenous treatment effects could be used to handle this shortcoming (Wooldridge, 2010).

In this study, we use production function approach to assess the relevance effect of fertilizer microdosing and identify the determinants of fertilizer microdosing adopters. The relationship between performance and these explanatory factors is defined as:

$$
Y_{i j}=\alpha X_{i j}+\theta M_{i j}+\varepsilon_{i j}
$$

with, $Y_{i j}$ standing for farmer $i$ yield from $\operatorname{plot} j, X_{i j}$ for agronomic, socio-economic and other production factors $M_{i j}$ for a binary variable taking 1 if the farmer $i$ applied fertilizer microdosing on the plot $j$ and 0 otherwise; $\varepsilon_{i j}$ is the error term , $\alpha$ parameters vectors of covariates, $\theta$ average fertilizer microdosing effect on yield. $M_{i j}$ cannot be considered as an exogenous variable. In fact, the decisions to apply fertilizer microdosing and expected output are done simultaneously. Moreover, the unobserved factors included in the error term that explains the yield are linked also to fertilizer microdosing application decision. Indeed, based on previous studies, the fertilizer microdosing application was linked directly to socio-economic factors such as access to credit called warrantage (Tabo et al., 2007; Fatondji et al., 2016). Warrantage is a system that facilitates access to credit, agricultural products and input markets. In addition, Fatondji et al. (2016) showed that training such as agronomic trials and demonstrations are key factors that could explain farmer's decisions to apply fertilizer microdosing. Some farmers pointed out that the lack of training was one reason why they did not apply fertilizer microdosing apart from financial and physical inaccessibility of fertilizer. Labor availability is also a key factor in fertilizer microdosing adoption decision (Okebalama et al., 2017; Liverpool-Tassie et al., 2015).

Thus, the relationship between fertilizer microdosing application and those factors is:

$$
M_{i j}=\delta D_{i j}+\mu_{i j}
$$

with $D_{i j}$ Vector of explanatory variables of fertilizer microdosing adoption by the farmer $i$ on the plot $j, \mu_{i j}$ error term, $\delta$ parameters vector. Because of endogeneity of $M_{i j}$, Ordinary Least Square cannot be used to estimate equation 1 (Wooldridge, 2010). To purge this variable of its endogeneity, we use a model called « endogenous treatment-regression model » (Cong and Drunker, 2001). From equation (1) and (2) the model is:

$$
\begin{aligned}
& Y_{i j}=\alpha X_{i j}+\theta M_{i j}+\varepsilon_{i j} \\
& M_{i j}= \begin{cases}1, & \text { if } \delta D_{i j}+\mu_{i j}>0 \\
0, & \text { otherwise }\end{cases}
\end{aligned}
$$

The model is composed of equations of the yield $Y_{i j}$ and the endogenous treatment $M_{i j}$. We assume that the covariates of equations (1) and (2) are uncorrelated to error terms. In addition, the error terms $\varepsilon_{i j}$ and $\mu_{i j}$ are bivariate normal with mean zero. The parameter $\theta$ is the average treatment effect (ATE). It is the average effect of fertilizer microdosing application on crop yield. When there is no interaction between $M_{i j}$ and one of $Y_{i j}$ covariates, the ATE is equal to the average treatment effect on the treated (ATET).

The translog production function is used because it does not imply a fixed elasticity of perfect substitution between the production factors nor the perfect functioning of the production factor market; also, its application makes it possible to determine the optimal level of the production factors with a tractability comparable to the CobbDouglass production function (Kouka et al., 1995; Pavelescu, 2011). However, interaction variables will not be included due to multicolinearity issue (Pender et al., 2008).

\section{Study area and data}

The study was conducted in the provinces of Oubritenga, Nahouri, Ziro, Kouritenga and Boulgou in Burkina Faso. 
Annual average rainfall is comprised between 600 and $1200 \mathrm{~mm}$. These different provinces are fertilizer microdosing diffusion areas and characterized by low soil fertility. In these regions, farmers cultivate maize and sorghum as main staple foods.

We used data from socio-economic surveys carried out in 2011 by the Institute for Environment and Agricultural Research (INERA) to assess the impact of the AGRA-Fertilizer microdosing project funded by the Alliance for the Green revolution in Africa (AGRA) implemented from 2008 to 2012 in Burkina Faso. The purpose of this project was to increase the production of millet, sorghum, cowpea and maize by $50 \%$ and the income by at least $30 \%$ for 130,000 agricultural households in Burkina Faso through large-scale dissemination and adoption of fertilizer microdosing and warrantage system. A sample of 1057 agricultural households was selected using stratified sampling method. The household heads were the only ones to be interviewed. In the absence of the household head, another family member who was able to answer has replaced him or her.

The data collected are farmer's socio-economic characteristics, agricultural practices and the agronomic characteristics of plots. In terms of adoption factors, access to credit is a key factor in developing countries (Martey et al., 2013; Akpan et al., 2012; Simtowe et al., 2014). In our case, we used the warrantage credit that boosted the adoption of fertilizer microdosing by facilitating access to mineral fertilizers (Tabo et al., 2007; Fatondji et al., 2016). Moreover, access to warrantage credit was linked to the specific characteristics of farmers. Thus, the distance of warrantage shops from the farmers' residence place and being membership of rural organization were used as proxies for access to credit. Access to extension services is also a key factor in the decision to adopt agricultural innovations (Diiro, 2013; Amare et al., 2011; Alene et al., 2000; Muzari et al., 2012). The effect of this variable on fertilizer microdosing adoption is assessed through participation in demonstration plots and agronomic trials. As fertilizer microdosing is a labor-intensive technology, total acreage of cropland could have a negative effect on the probability of adoption. In addition, control variables such as age, level of education, gender, agro-ecological area; may also influence the probability of fertilizer microdosing adoption (Feder et al., 1985; Adesina et al., 1995; Fufa and Hassan, 2010; Liverpool-Tasie et al., 2015; Mwangui and Kariuki, 2015). To assess the impact of fertilizer microdosing, we control for the biophysical characteristics of plots according to farmers' perceptions and the effects of inputs on yield (Pender et al., 2008). Amongst the characteristics of the plots, we have crop rotation, type of soil, topo sequence, intercropping, distances of plots from residence, plot-ploughing, access to land and sowing period. For the inputs use, we have the quantity of fertilizer $(\mathrm{kg} / \mathrm{ha})$, the application of manure and fertilization periods. Socio-economic include farmers' assets, livestock value, marital status, age, gender, level of education and off-farm income.

\section{Results and discussion}

\subsection{Fertilizer application methods on sorghum and maize plots}

Table 1 represents the fertilization methods used by farmers. Farmers are prone to fertilize maize plots compared to sorghum plots, particularly in Nahouri and Ziro provinces. These findings can be explained by the favorable climate conditions for maize production in Burkina Faso. Moreover, maize farmers are market-oriented and their income selling maize sometimes finance their family expenses. Across fertilizer method, most farmers spread fertilizer in spot. However, in the Plateau-Central, most of them applied fertilizer microdosing compared to other regions. Indeed, in the past, fertilizer microdosing was widely disseminated in plateau central region.

Table 1: Fertilizer application methods across provinces in percentage

\begin{tabular}{|c|c|c|c|c|c|c|}
\hline \multirow{2}{*}{$\begin{array}{l}\quad \text { Area and crops } \\
\text { Fertilization } \\
\text { methods }\end{array}$} & \multicolumn{2}{|c|}{$\begin{array}{l}\text { Centre-Ouest } \\
\text { (Nahouri, Ziro) }\end{array}$} & \multicolumn{2}{|c|}{$\begin{array}{c}\text { Plateau Central } \\
\text { (Oubritenga, } \\
\text { Ganzourgou) }\end{array}$} & \multicolumn{2}{|c|}{$\begin{array}{c}\text { Centre-Est (Boulgou, } \\
\text { Koulpelogo, Kouritenga) }\end{array}$} \\
\hline & Sorghum & Maize & Sorghum & Maize & Sorghum & Maize \\
\hline Without fertilizer & 58.37 & 37.57 & 68.03 & 52.38 & 68.34 & 47.13 \\
\hline $\begin{array}{l}\text { Fertilizer } \\
\text { microdosing(buried } \\
\text { ) }\end{array}$ & 12.67 & 18.05 & 14.34 & 28.57 & 9.11 & 13.52 \\
\hline $\begin{array}{l}\text { Spot application } \\
\text { (not buried) }\end{array}$ & 28.96 & 44.39 & 17.67 & 19.05 & 22.55 & 39.34 \\
\hline
\end{tabular}




\subsection{Analysis of yield distribution by crop}

Table 2 presents the distribution of crop yields across fertilization methods and area. Overall, most fertilized plots have a higher average yield than unfertilized plots. The average yields of sorghum were above $500 \mathrm{~kg} / \mathrm{ha}$ in almost all regions. The highest yields of sorghum were observed in the Centre-Est region estimated at about $800 \mathrm{~kg} / \mathrm{ha}$ (fertilizer microdosing). For maize, fertilizer microdosing plots have the highest production per hectare estimated at $745 \mathrm{~kg}$ in the Centre-Est region. Across fertilizer application methods, all yields of fertilizer microdosing plots are greater than $550 \mathrm{~kg} / \mathrm{ha}$ in all regions compared to spot fertilization methods for both crops.

Table 2: Average yield across fertilization methods $(\mathrm{kg} / \mathrm{ha})$

\begin{tabular}{|c|c|c|c|c|c|c|c|}
\hline \multirow[b]{2}{*}{$\begin{array}{l}\text { Fertilization } \\
\text { methods }\end{array}$} & \multirow{2}{*}{$\begin{array}{l}\text { Area } \\
\text { and } \\
\text { crops }\end{array}$} & \multicolumn{2}{|c|}{$\begin{array}{l}\text { Centre-Ouest } \\
\text { (Nahouri, Ziro) }\end{array}$} & \multicolumn{2}{|r|}{$\begin{array}{l}\text { Plateau Central } \\
\text { (Oubritenga, } \\
\text { Ganzourgou) }\end{array}$} & \multicolumn{2}{|c|}{$\begin{array}{c}\text { Centre-Est (Boulgou, } \\
\text { Koulpelogo, } \\
\text { Kouritenga) }\end{array}$} \\
\hline & & $\mathrm{n}$ & $\begin{array}{c}\text { Average yield } \\
\text { (standard- } \\
\text { deviation) }\end{array}$ & $\mathrm{n}$ & $\begin{array}{l}\text { Average yield } \\
\text { (standard- } \\
\text { deviation) }\end{array}$ & $\mathrm{n}$ & $\begin{array}{l}\text { Average yield } \\
\text { (standard- } \\
\text { deviation) }\end{array}$ \\
\hline \multirow{2}{*}{$\begin{array}{l}\text { Without } \\
\text { fertilizer }\end{array}$} & Sorghum & 129 & $470.83(376.32)$ & 166 & $415.18(353.50)$ & 300 & $604.05(430.82)$ \\
\hline & Maize & 77 & $564.84(412.98)$ & 33 & $607.45(445.65)$ & 115 & $454.40(405.52)$ \\
\hline \multirow{2}{*}{$\begin{array}{l}\text { Spot } \\
\text { application }\end{array}$} & Sorghum & 64 & $571.18(391.53)$ & 43 & $566.72(400.24)$ & 99 & $590.05(441.38)$ \\
\hline & Maize & 91 & $687.07(478.21)$ & 18 & $658.33(481.42)$ & 96 & $512.83(376.03)$ \\
\hline \multirow{2}{*}{$\begin{array}{l}\text { Fertilizer } \\
\text { microdosing }\end{array}$} & Sorghum & 28 & $528.95(284.86)$ & 35 & $615.57(401.26)$ & 40 & $796.29(511.49)$ \\
\hline & Maize & 37 & $568.94(423.34)$ & 12 & $637.78(284.40)$ & 33 & $745.35(475.11)$ \\
\hline
\end{tabular}

\subsection{Model estimation}

Table 3 represents the estimation of the model using maximum likelihood method. On the one hand, we have fertilizer microdosing adoption factors and on the other hand, the effect of fertilizer microdosing and other covariates on sorghum and maize yield.

Firstly, Wald's test indicates that the model fits well overall and is statistically significant. In addition, based on Likelihood ratio test, we can reject the hypothesis of no correlation between the treatment errors and the outcome errors. In other words, we could note the decision to adopt the fertilizer microdosing and the production decision are not separable.

Secondly, the endogenous treatment equation estimation shows that the distance from farmers' place of residence to input shops influences negatively and significantly the probability of applying fertilizer microdosing to sorghum. This finding is consistent with the results of some previous studies, which highlighted that access to warrantage helps farmers overcome the inputs constraints (Tabo et al., 2007; Ouattara et al., 2018; Pender et al., 2008). Being a member of rural organization can improve positively and significantly the probability of applying fertilizer microdosing to maize and sorghum. Indeed, the farmers who are members of rural organization were more likely to obtain credit through warrantage (Tabo et al., 2007; Garrido and Sànchez, 2015). In addition, farmers who are members of an organization are often more likely to participate in fertilizer microdosing training set up by the project. The partial effect of cropland is negative and significant on decision to apply fertilizer microdosing to both crops. This is consistent with the findings of some studies (Pender et al., 2008; Liverpool-Tasie et al., 2015). As fertilizer microdosing is labor-intensive technology, farmers with labor constraints are likely to adopt traditional methods, especially those with large farms. In terms of access to fertilizer microdosing training, participation in demonstrations plots of fertilizer microdosing and participation in agronomic trials have a positive and significant effect on the probability to apply fertilizer microdosing. These farmers had greater accessed to information regarding the fertilization methods. Farmers living in Ziro province will be more likely to apply fertilizer microdosing to sorghum and maize plots due to the access to fertilizers. Indeed, these farmers receive fertilizers on credit from Cotton Company for their cereals like maize in order to avoid the diversion of fertilizers intended for the production of cotton (Maître d'Hôtel and Porgo, 2018). However, there is a significant negative effect on the probability of adopting the fertilizer microdosing under maize in Kouritenga province. 
In terms of impact, the average treatment effect of fertilizer microdosing is positive and significant on both maize and sorghum yields. As there are no interaction variables between application of fertilizer microdosing and others covariates in the production function, this effect is the average treatment effect on the treats. We carried out a test by putting an interaction term and re-estimated the model. We found that the average treatment effect of fertilizer microdosing on the treats and the average treatment effect are closed ${ }^{1}$. Hence, the average treatment effect of fertilizer microdosing for the adopters is similar to the average treatment effect for whole farmers. The average treatment effect of fertilizer microdosing on sorghum and maize yield are $55 \%$ and $37 \%$ respectively. In other words, fertilizer microdosing application on sorghum can on average increase the yield approximately by $55 \%$ given others factors. This is consistent with the findings of studies which highlighted that fertilizer microdosing increased significantly crop yield (Pender et al., 2008; Sime and Aune, 2014; Okebalama et al., 2016). Tabo et al. (2007) using data from farm test field, found that sorghum yield under fertilizer microdosing was $106 \%$ greater than the control in Burkina Faso. In Ghana, Okebalama et al. (2016) obtained that fertilizer microdosing treatment increase maize yield by 32 to $99 \%$ across cropping system and soil types.

In addition, the analysis shows that other agronomic and socio-economic factors have significant positive or negative effects on the yield level of sorghum and maize. As agronomic and other fixed factors, sandy-clay and silty soils have a positive and significant effect on sorghum and maize yields respectively. Sowing in May has a negative and significant influence on the average crop yield compared to June. However, sowing in July seems adequate because there is a positive and significant average effect on maize yield estimated at $14 \%$ but not significant on sorghum's yield. For fertilizer application, its average effect on the yield of both crops is positive and significant. When the amount of fertilizer per hectare increases by $10 \%$, on average the yield of maize and sorghum increases approximately by $0.40 \%$ and $0.60 \%$ respectively. These results show that mineral fertilization may lead to get higher yields. Although the average effect is not significant, the use of organic fertilizers such as compost or manure can increase the yield level of sorghum and maize. For socio-economic variables, the results highlight that male plot managers have higher yields than women do, but the effect is not significant. The average effect of livestock's value on the yield is positive and significant in accordance with the literature on both crops. Indeed, livestock represent financial resources that can facilitate access to inputs and organic manure to maintain soil fertility. Given other factors, increasing at $10 \%$ the value of livestock on average leads increasing maize and sorghum yield to $0.32 \%$ and $0.40 \%$ respectively. In fact, the revenue from livestock selling is sometimes used to purchases fertilizers or farm labor. Compared to Boulgou, the farmers from the provinces of Kouritenga and Ziro could increase their production level of sorghum than whose of Oubritenga and Nahouri. In addition, maize's farmers living in Ziro province could also increase the average yield due to favorable rainfall conditions and market-oriented production.

Table 3: Endogenous treatment-regression model estimation

\begin{tabular}{llcccc}
\hline \multirow{2}{*}{ Variables } & & \multicolumn{2}{c}{ Sorghum } & \multicolumn{2}{c}{ Maize } \\
\hline Crop rotation (yes/no) & & Coefficients & Z-score & Coefficients & z-score \\
\cline { 2 - 5 } & Clay & -0.03 & -0.61 & 0.12 & 1.54 \\
Soil type (ref. sandy) & Sandy and clay & 0.003 & 0.05 & 0.09 & 1.03 \\
& Loam & 0.12 & $1.77 *$ & -0.06 & -0.67 \\
& Top & 0.10 & 1.06 & 0.44 & $2.53^{* *}$ \\
Topo sequence land & Valley & -0.02 & -0.40 & 0.09 & 0.96 \\
(ref. slope) & upslope & -0.02 & -0.38 & -0.20 & $-2.25^{* * *}$ \\
& downslope & 0.36 & $3.24 * * *$ & -0.22 & -1.04 \\
& Valley and upslope & 0.23 & 1.03 & 0.07 & 0.29 \\
Distance from & 1 km & 0.11 & 0.60 & -0.69 & $-2.76^{* * *}$ \\
residence (ref. $0.5 \mathrm{~km})$ & $>1$ km & 0.07 & 1.03 & 0.14 & 1.34 \\
\hline
\end{tabular}

\footnotetext{
${ }^{1}$ The average treatment effect on the treated (ATET) of fertilizer microdosing on sorghum and maize yield are 0.56 and 0.37 respectively.
} 
Journal of Economics and Sustainable Development

\begin{tabular}{|c|c|c|c|c|c|}
\hline \multirow{2}{*}{$\begin{array}{l}\text { Plot access (cf } \\
\text { inherited) }\end{array}$} & Rented & -0.24 & -1.32 & -0.03 & -0.11 \\
\hline & Mortgaged & -0.28 & -1.32 & 0.21 & 0.86 \\
\hline \multicolumn{2}{|l|}{ Ploughing (yes/no) } & 0.10 & 1.35 & 0.14 & 1.45 \\
\hline \multirow{2}{*}{$\begin{array}{l}\text { Sowing period (ref. } \\
\text { June) : yes/no }\end{array}$} & May & -0.09 & -1.47 & -0.20 & $-1.92 *$ \\
\hline & July & 0.05 & 0.52 & 0.14 & $1.67 *$ \\
\hline \multicolumn{2}{|l|}{ Intercropping (yes/no) } & 0.18 & $3.26 * * *$ & 0.16 & $2.05 * *$ \\
\hline \multicolumn{2}{|c|}{ Organic manure (yes/no) } & 0.01 & 0.25 & 0.10 & 1.36 \\
\hline \multicolumn{2}{|c|}{ Ln (quantity of fertilizer /ha) } & 0.04 & $2.59 * *$ & 0.06 & $2.83 * * *$ \\
\hline \multirow{2}{*}{$\begin{array}{l}\text { Fertilizer applicatio } \\
\text { period (ref. } 1^{\text {st }} \\
\text { weeding): yes/no }\end{array}$} & At sowing & -0.15 & -1.30 & -0.07 & -0.48 \\
\hline & $2^{\text {nd }}$ weeding & -0.17 & -0.88 & -0.20 & -1.01 \\
\hline \multicolumn{2}{|c|}{ Ln (Labor-to-land ratio :person/ha) } & 0.20 & $6.70 * * *$ & 0.15 & $3.55 * * *$ \\
\hline \multicolumn{2}{|l|}{ Age(years) } & 0.00 & 0.18 & -0.00 & -0.70 \\
\hline \multicolumn{2}{|l|}{ Gender (Male/female) } & 0.00 & 0.03 & 0.26 & 1.62 \\
\hline \multicolumn{2}{|c|}{ Marital status (married/no) } & -0.11 & -0.72 & 0.15 & 0.66 \\
\hline \multirow{3}{*}{$\begin{array}{l}\text { Education level (ref } \\
\text { none) : yes/no }\end{array}$} & Primary & 0.02 & 0.35 & 0.01 & 0.15 \\
\hline & Secondary & 0.10 & 0.83 & -0.01 & -0.05 \\
\hline & Literacy training & 0.03 & 0.45 & 0.07 & 0.61 \\
\hline $\begin{array}{l}\text { Main activity (ref. } \\
\text { farmers) }\end{array}$ & Off-farm activity & 0.06 & 0.83 & -0.07 & -0.84 \\
\hline \multicolumn{2}{|c|}{ Ln (value of livestock /FCFA) } & 0.03 & $2.59 * * *$ & 0.04 & $2.94 * * *$ \\
\hline \multicolumn{2}{|c|}{ Ln (off-farm income/FCFA) } & -0.01 & -1.36 & 0.00 & 0.74 \\
\hline \multirow{4}{*}{$\begin{array}{l}\text { Provinces (ref. } \\
\text { Boulgou) : yes/no }\end{array}$} & Kouritenga & 0.18 & $2.06 * *$ & -0.52 & $-3.94 * * *$ \\
\hline & Oubritenga & -0.25 & $-2.87 * * *$ & -0.21 & -1.65 \\
\hline & Nahouri & -0.12 & -1.21 & -0.19 & -1.56 \\
\hline & Ziro & 0.15 & 1.63 & 0.10 & 0.95 \\
\hline \multicolumn{2}{|c|}{ Fertilizer microdosing (yes/no) } & 0.55 & $2.93 * * *$ & 0.37 & $1.66^{*}$ \\
\hline \multicolumn{2}{|l|}{ Constant } & 5.11 & $21.39 * * *$ & 4.50 & $14.26^{* * *}$ \\
\hline \multicolumn{6}{|c|}{ Fertilizer microdosing adoption factors } \\
\hline \multicolumn{2}{|l|}{ Age } & -0.01 & $-2.24 * *$ & 0.00 & 0.59 \\
\hline \multicolumn{2}{|l|}{ Gender (Male/female) } & 0.06 & 0.23 & -0.03 & -0.12 \\
\hline \multirow{3}{*}{$\begin{array}{l}\text { Education level (ref. } \\
\text { none) : yes/no }\end{array}$} & Primary & -0.01 & -0.08 & 0.29 & 1.42 \\
\hline & Secondary & $-0,38$ & -1.00 & -0.45 & -0.85 \\
\hline & Literacy training & 0.09 & 0.50 & 0.33 & 1.37 \\
\hline \multicolumn{2}{|c|}{ Members of farmers' organization (yes/no) } & 0.25 & $1.71 * *$ & 0.42 & $2.42 * *$ \\
\hline \multicolumn{2}{|c|}{ Ln (distance to warrantage shop $/ \mathrm{km}$ ) } & -0.02 & $-2.30 * *$ & -0.02 & $-1.72 *$ \\
\hline \multicolumn{2}{|c|}{$\begin{array}{l}\text { Participation in fertilizer microdosing } \\
\text { demonstration (yes/no) }\end{array}$} & 0.25 & $3.47 * * *$ & 0.37 & $3.90 * * *$ \\
\hline
\end{tabular}




\begin{tabular}{|c|c|c|c|c|c|}
\hline \multicolumn{2}{|c|}{$\begin{array}{l}\text { Participation in fertilizer microdosing } \\
\text { application trials (yes/no) }\end{array}$} & 0,76 & $5.47 * * *$ & 0.52 & $2.91 * * *$ \\
\hline \multicolumn{2}{|l|}{ Ln (plot area/ha) } & -0.41 & $-4.44 * * *$ & -0.51 & $-4.21 * * *$ \\
\hline \multicolumn{2}{|c|}{ Ln (Value of livestock/FCFA) } & 0.02 & 0.52 & -0.00 & -0.05 \\
\hline \multicolumn{2}{|c|}{ Ln (off-farm income/CFA) } & 0.00 & 0.62 & -0.01 & -0.66 \\
\hline & Kouritenga & 0.05 & 0.27 & -0.69 & $-2.24 * *$ \\
\hline Provinces (ref. & Oubritenga & 0.19 & 1.01 & -0.33 & -1.26 \\
\hline \multirow[t]{2}{*}{ Boulgou): yes/no } & Nahouri & 0.18 & 0.76 & 0.11 & 0.51 \\
\hline & Ziro & 0.51 & $2.29 * *$ & 0.40 & $1.78^{*}$ \\
\hline \multicolumn{2}{|l|}{ Constant } & -1.70 & $-3.18 * * *$ & -1.79 & $-3.37 * * *$ \\
\hline \multicolumn{2}{|l|}{ Rho ( $\rho)$} & -0.39 & & -0.32 & \\
\hline \multicolumn{2}{|l|}{$\operatorname{Sigma}(\sigma)$} & 0.70 & & 0.32 & \\
\hline \multicolumn{2}{|c|}{ Number of observations } & 904 & & 512 & \\
\hline \multicolumn{2}{|l|}{ Wald chi2(36) } & 235.73 & & 148.05 & \\
\hline \multicolumn{2}{|c|}{ LR test of indep. eqns. $($ rho $=0)$} & $\operatorname{Chi}(1)=5.55$ & $\begin{array}{c}\text { Prob }>\text { chi } \\
2=0.01\end{array}$ & $\operatorname{Chi}(1)=2.80$ & $\begin{array}{l}\text { Prob }>\text { chi } 2 \\
\quad=0.09\end{array}$ \\
\hline
\end{tabular}

Note: $* * *, * *, *$ denote significance at $1 \%, 5 \%$ and $10 \%$ respectively.

\section{Conclusion and recommendations}

The purpose of this study was to identify the determinants of fertilizer microdosing fertilization and to evaluate its impact on sorghum and maize yields in Burkina Faso using a production function approach taking into account farm-level heterogeneity.

Using the endogenous treatment-regression model, the estimation of the model highlighted that access to credit through warrantage, participation in fertilizer microdosing application demonstrations and agronomic trials are the main factors of fertilizer microdosing adoption by rural farmers. However, large farms tend to follow the traditional method because it requires less labor. In terms of impact, fertilizer microdosing has a positive and significant average effect on sorghum and maize yields given other factors. In other words, fertilizer microdosing application can lead to achieve higher yields than traditional fertilizer method. In addition, the findings shows the importance to mechanize the application of fertilizer microdosing, which could lead a large adoption by the farmers. We also note the importance of setting up credit access mechanisms such as warrantage with the built of warrantage shops, capacity building to facilitate access to fertilizer and information's and mechanization of fertilizer microdosing application. Future studies should use a panel data model to investigate the continued use of fertilizer microdosing in order to assess its impact on farmers' agricultural production and income over time.

\section{References}

Adesina, A.A. \& Baidu-Forson, J. (1995), "Farmers' perception and adoption of new agricultural technology: evidence from analysis in Burkina Faso and Guinea, West Africa", Agricultural Economics 13, Elsevier 1-9.

Akpan, S.B., Nkanta, V.S. \& Essien, U.A. (2012), “A Double-Hurdle Model of Fertilizer Adoption and Optimum Use among Farmers in Southern Nigeria”, Tropicultura 30(4), 249-253,

Alene, A.D., Poonyth, D. \& Hassan, R.M. (2000), "Determinants of adoption and intensity of use of improved maize varieties in the central highlands of Ethiopia: a Tobit Analysis", Agrekon 39(4), 633-643.

Amare, M., Asfaw, S. \& Shiferaw, B. (2012), "Welfare impacts of maize-pigeonpea intensification in Tanzania", Agricultural Economics, 43(1), 27-43.

Aune, J. B. \& Bationo, A. (2008), “Agricultural intensification in the Sahel-The ladder approach”, Agricultural systems 98 , Elsevier, 119-125. 
Bado, B.V., Bationo, A., Lompo, F., Cescas, M.P. \& Sedogo, M.P. (2007), “Mineral fertilizers, organic amendments and crop rotation managements for soil fertility maintenance in the Guinean zone of Burkina Faso (West Africa)", In: Bationo A., Waswa B., Kihara J. \& Kimetu J. (eds), Advances in Integrated Soil Fertility Management in subSaharan Africa: Challenges and Opportunities, Springer, Dordrecht, pp.171-177.

Bagayoko, M., Maman, N., Palé, S., Sirifi, S., Taonda, S.J.B., Traore, S. \& Mason, S.C. (2011), "Microdose and $\mathrm{N}$ and $\mathrm{P}$ fertilizer application rates for pearl millet in West Africa", African Journal of Agricultural Research 6(5), 1141-1150.

Cong, R. \& D. M. Drukker. (2000), “Treatment effects model”, Stata Technical Bulletin 55: 25-33. Reprinted in Stata Technical Bulletin Reprints, 10, 159-169. College Station, TX: Stata Press.

Diiro, G.M. (2013), "Impact of off-farm income on agricultural technology adoption intensity and productivity: Evidence from rural maize farmers in Uganda”, Working paper 11, IFPRI, Strategy support program, Uganda.

Fatondji, D., Taonda, S.J.B., Sogodogo, M., Mamane,S. \& Zida, Z.(2016), "Taking microdosing to scale in the sahel". In: AGRA. (ed), Going Beyond Demos to Transform African Agriculture: The Journey of AGRA's Soil Health Program, Nairobi, pp. 39-53.

Feder, G., Just, R. E., \& Zilberman, D. (1985), “Adoption of agricultural innovations in developing countries: A survey”, Economic development and cultural change 33(2), 255-298.

Food and Agriculture Organization of the United Nations. (2013), Analyse des incitations par les prix pour le sorgho au Burkina Faso, Rome, p.7.

Fufa, B. \& Hassan, R.M. (2006), "Determinants of fertilizer use on maize in Eastern Ethiopia: A weighted endogenous sampling analysis of the extent and intensity of adoption”, Agrekon, 45(1), 38-49.

Garrido,E.S. \& Sanchez, I.S. (2015), Warrantage paysan au Burkina Faso :accès au crédit par le biais des stocks de proximité, Rapports de recherche, Oxfam GB, Oxford, p.61.

Hayashi, K., Abdoulaye, T., Gerard, B. \& Bationo, A. (2008), "Evaluation of application timing in fertilizer microdosing technology on millet production in Niger, West Africa", Nutrient Cycling in Agroecosystems 80(3), $257-$ 265.

Holtzman, J.S., Kaboré, D., Tassembedo, M. \& Adomayakpor, R. (2013), Burkina Faso: Indicateurs de l'agrobusiness, DC: World Bank Group, Washington, p.161.

Kouka, P.J., Jolly, C. \& Henao, J. (1995), “Agricultural response functions for limited resource farmers in SubSaharan Africa”, Fertilizer Research 40 (2), 135-141.

Liverpool-Tasie, L.S.O., Sanou, A. \& Mazvimavi, K. (2015), "How profitable is sustainable intensification? The case of fertilizer micro-dosing in Niger", In AAEA and WAEA Joint Annual Meeting, San Francisco, pp. 26-28.

Maître d'Hôtel, E. \& Porgo, I. (2018). Quelles actions politiques pour renforcer l'accès des producteurs agricoles à des engrais chimiques à prix réduits au Burkina Faso ? Rapport d'analyse de politique, SAPAA, FAO, Rome, p.45.

Martey, E., Wiredu, A.N., Etwire, P.M., Fosu, M., Buah, S.S.J., Bidzakin, J., Ahiabor, B.D. K. \& Kusi. F.(2014), "Fertilizer adoption and use intensity among smallholder farmers in northern Ghana: A Case Study of the AGRA Soil Health Project", Sustainable Agriculture Research 3(1).

Muzari, W., Gatsi, W and Muvhunzi, S. (2012), “The Impacts of Technology Adoption on Smallholder Agricultural Productivity in Sub-Saharan Africa: A Review”, Journal of Sustainable Development 5 (8), 69.

Mwangi, M. \& Kariuki, S. (2015), "Factors determining adoption of new agricultural technology by smallholder farmers in developing countries", Journal of economics and sustainable development 6(5).

Okebalama, C.B., Abaidoo, R. \& Logah, V. (2016), "Fertilizer microdosing in the humid forest zone of Ghana : An efficient strategy for increasing Maize yield and income", Soil science society of America journal, 80(5), $1254-$ 1261 .

Okebalama, C.B., Ibrahim, A., Safo, E.Y., Yeboah, E., Abaidoo, R.C., Logah,V. \& Monica, U.F. (2017), "Fertilizer microdosing in West Africa low-input cereals cropping: benefits, challenges and improvements strategies", African journal of agricultural research 12(14), 1169-1176.

Ouattara, B., Taonda, S.J.B., Traoré, A., Serme, I., Lompo, F., Peak, D., Sedogo, M.P. \& Bationo, A. (2018), "Use of a warrantage system to face rural poverty and hunger in the semi-arid area of Burkina Faso", Journal of development and agricultural economics 10(2), 55-63. 
Pavelescu, F. M. (2011), “Some aspects of the translog production function estimation", Romanian Journal of Economics 32(1), 131-150.

Pender, J., Abdoulaye, T., Ndjeunga, J., Gerard, B. \& Kato, E. (2008), "Impacts of inventory credit, input supply shops, and fertilizer microdosing in the drylands of Niger”, Discussion Paper 00763, Intl Food Policy Res Inst.

Sime, G. \& Aune, J.B. (2014), "Maize response to fertilizer dosing at three sites in the Central Rift Valley of Ethiopia", Agronomy 4(3), 436-451.

Simtowe, F. P. \& Zeller, M. (2006), "The Impact of Access to Credit on the Adoption of Hybrid Maize in Malawi: An Empirical Test of an Agricultural Household Model Under Credit Market Failure", [Online]. Available at: https://papers.ssrn.com/sol3/papers.cfm?abstract_id=939515. [Accessed 15 jan.2019].

Tabo, R., Bationo, A., Bruno, G., Ndjeunga, J., Marcha, D., Amadou, B., Annou, M.G., Sogodogo, D., Taonda, S.J.B., Ousmane, H., Diallo, M.K. \& Koala, S. (2007), "Improving cereal productivity and farmers, income using a strategic application of fertilizers in West Africa", In: Bationo. A., Waswa, B.S., Kihara, J., Kimetu, J. (eds), Advances in integrated soil fertility management in sub-Saharan Africa: Challenges and opportunities, pp 201208.

Vanlauwe, B., Coyne, D., Gockowski, J., Hauser, S., Huising, J., Masso, C. \& Van Asten, P. (2014), "Sustainable intensification and the African smallholder farmer", Current Opinion in Environmental Sustainability 8(0),15-22.

Wooldridge, J.M. (2010), Econometric analysis of cross section and panel data, MIT pres. 